\title{
Delayed Pericardial Tamponade after Nail Gun Injury to the Right Ventricle
}

\author{
Kamal YA \\ Department of Cardiothoracic Surgery, Minia University Hospital, El-Minia, Egypt
}

*Corresponding author: Kamal YA, Department of Cardiothoracic Surgery, Minia University Hospital, El-Minia, Egypt, Fax: 002-0862342501, Tel: 002-01123234736 E-mail: yaser_ali_kamal@yahoo.com

Citation: Kamal YA (2018) Delayed Pericardial Tamponade after Nail Gun Injury to the Right Ventricle. SAJ Case Rep 5: 303

Article history: Received: 23 May 2018, Accepted: 03 August 2018, Published: 06 August 2018

\begin{abstract}
The use of nail guns has been expanded since 1950s, as it requires a minimum training. Nail guns can fire projectiles at a rapid speed for a distance up to 500 meters. Cardiac nail gun injuries are rare but life-threatening. Most of the cases presented within few minutes after injury and associated with hemodynamic compromise and some degree of pericardial tamponade. We describe a case of 19-years-old carpenter presented 15 hours after nail gun injury without hemohynamic compromise. Chest CT detected penetration of the nail tip in the pericardium with pericardial effusion. The hemodynamic status deteriorated during diagnostic workup. The bedside echocardiography revealed tamponading pericardial effusion. Through the left anterior thoracotomy, intrapericardial hematoma was removed, the nail was successfully extracted, and a laceration in the right ventricle was repaired. The postoperative course was uneventful. In conclusion, nail gun should be considered as one of the essential causes of penetrating cardiac injury. High index of suspicion and appropriate imaging studies result in successful management of hemodynamically stable patients. An aggressive approach without time consuming investigations is preferred for unstable patients after penetrating cardiac injury.
\end{abstract}

Keywords: Cardiac Injury; Nail Gun Injury; Penetrating Trauma; Pericardial Tamponade

\section{Introduction}

Penetrating cardiac injury is an emergent condition which has a high rate of mortality. Alive patients have a variable clinical presentation at the emergency department with a pericardial tamponade in $70 \%$ of survivors and $20 \%$ of non-survivors [1]. Firearm and stab wounds are the most common causes of penetrating cardiac injury [2].

Nail guns have been used since 1950s to fire nails into woods, concrete and metal surfaces, with the ability to fire projectiles at a speed of 100-150 meters/second and distances of up to 500 meters [3]. Increasing the use of nail guns, as it requires a minimum training, has been reported to increase the rate of nail gun injuries [4]. Extremities are the most common site susceptible to accidental trauma, while penetrating cardiac injury is much less common injury secondary to discharge of pneumatic nail gun [5].

Nail gun cardiac injuries are fairly rare entity, mostly reported in adult males, due to working related infliction with a nail with a death risk of 25\% [6]. Searching Medline on July 2018 determined only 25 published case reports of nail gun cardiac injuries. In most of the reported cases, patients survive as the nail wedges in the soft tissue even when there is a chamber injury. Eleven case reports, described 13 patients presented with stable hemodynamic status or had delayed presentation after cardiac nail gun injuries (Table 1).

\section{Methodology}

We reported a rare case with delayed presentation of pericardial tamponade after cardiac nail gun injury. We described clinical features, results of imaging studies, surgical procedure and postoperative outcome. Also, we review the literature by searching MEDLINE for similar cases of cardiac nail gun injuries using keywords of (cardiac injury) and (nail gun).

\section{Results}

A 19-years-old male presented at the emergency department 15 hours after nail gun injury during his work as a carpenter. The patient did not notice the entrance of the nail and he thought it hit him and came on the ground. He asked for medical advice 
at a primary care center after development of severe chest pain, where he was referred to our university hospital. The physical examination revealed pinpoint skin wound at the right side of the sternum along the intermammary line (Figure 1). The patient was fully conscious and his vital signs were: blood pressure $90 / 60 \mathrm{~mm} \mathrm{Hg}$, heart rate 100 beats/min, and respiratory rate 18 breaths/ min. Peripheral venous and arterial lines and urinary catheter were inserted.

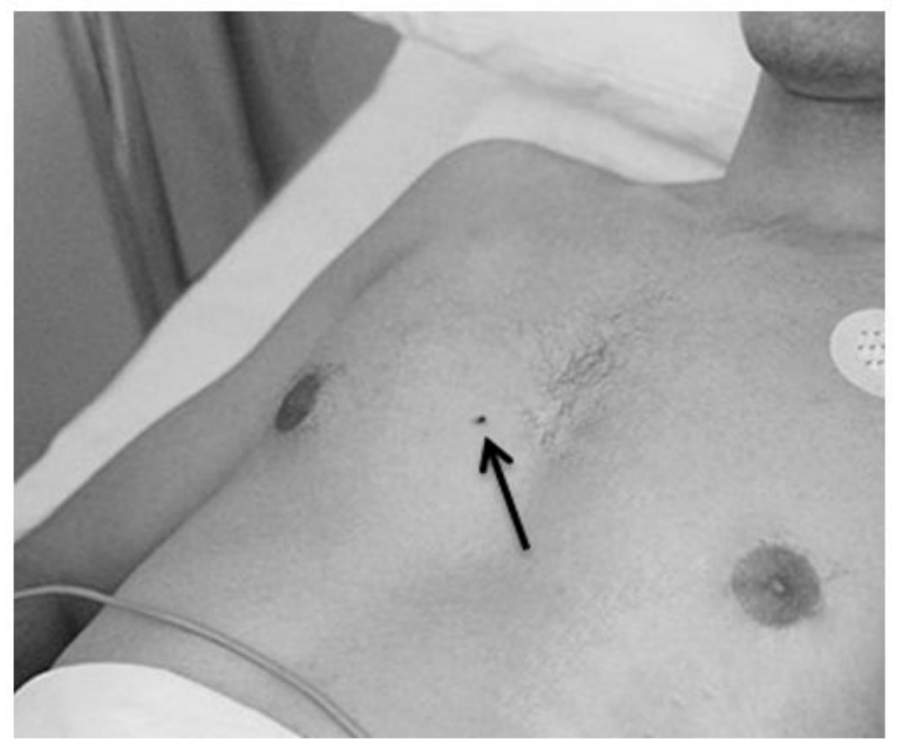

Figure 1: Chest X-ray anterior- posterior view shows previous pneumonectomy with ipsilateral mediastinal shift (indicated by an arrow)

Computed tomography (CT) scan was performed and revealed right parasternal nail penetrating through the soft tissue, costal cartilage and pericardium associated with pericardial effusion (Figure 2). After CT scanning, the patient became drowsy with deterioration of vital signs: blood pressure $85 / 50 \mathrm{~mm} \mathrm{Hg}$, heart rate 110 beats/min, and respiratory rate 20 breaths/min. Bedside echocardiography revealed tamponading pericardial effusion with collapse of the right ventricle during diastole (Figure 3). Thereafter, the patient was transferred immediately to the operating room. Left anterior thoracotomy revealed penetration of the nail tip into pericardium through a small hole, with hemopericardium and large hematoma over the right side of the heart. After evacuation of the hematoma, a small puncture at the anterior surface of right ventricle was observed and started to re-bleed after removal of the hematoma. The bleeding from the puncture was initially controlled by digital pressure. A 4-cm nail (Figure 4) was removed outward through its track from the pericardium, costal cartilage and soft tissue. The direct repair of the right ventricular injury was performed with two 3/0 Prolene sutures (Figure 5). The patient developed no post-operative complications and he was discharged home at the 5 th day after surgery.

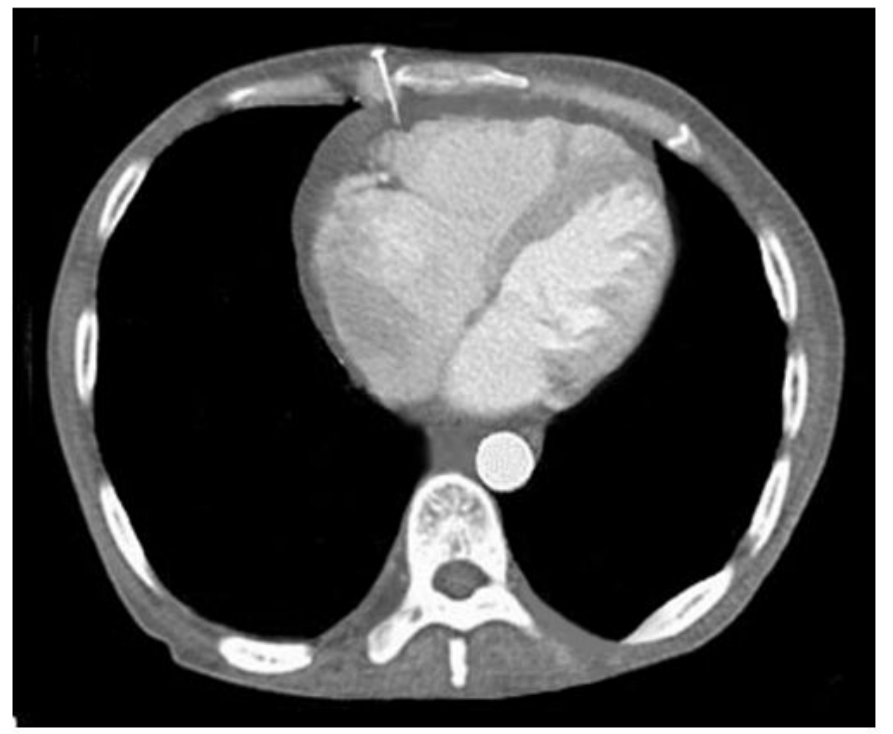

Figure 2: Axial view of chest computed tomography showing a nail passing through the sternum and pericardium with pericardial effusion 


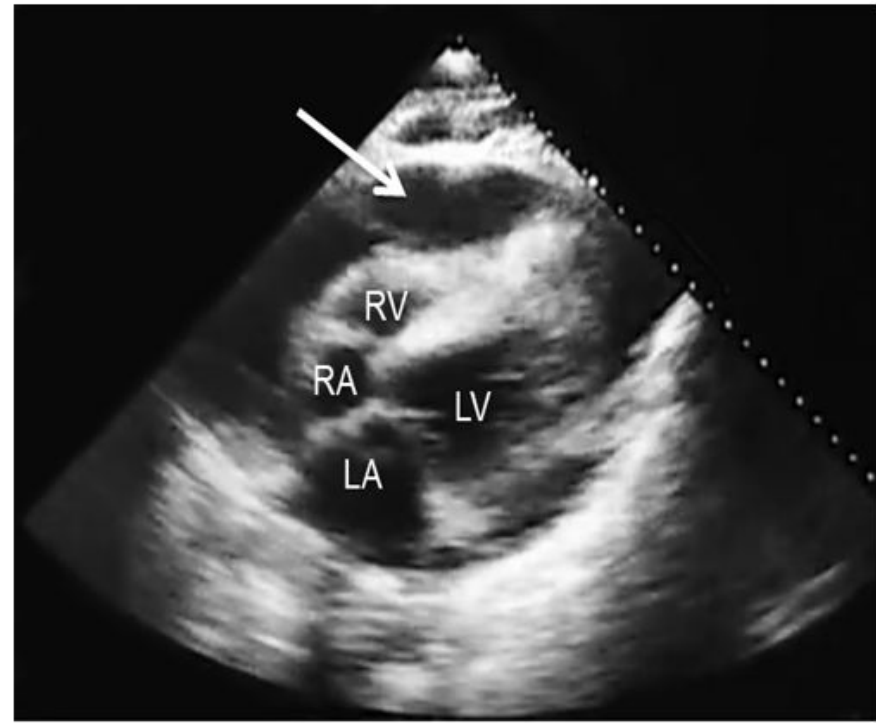

Figure 3: Bedside transthoracic echocardiographic view showing pericardial effusion (arrow) with right ventricular collapse during diastole. RV: right ventricle, RA: right atrium, LV: left ventricle, LA: left atrium

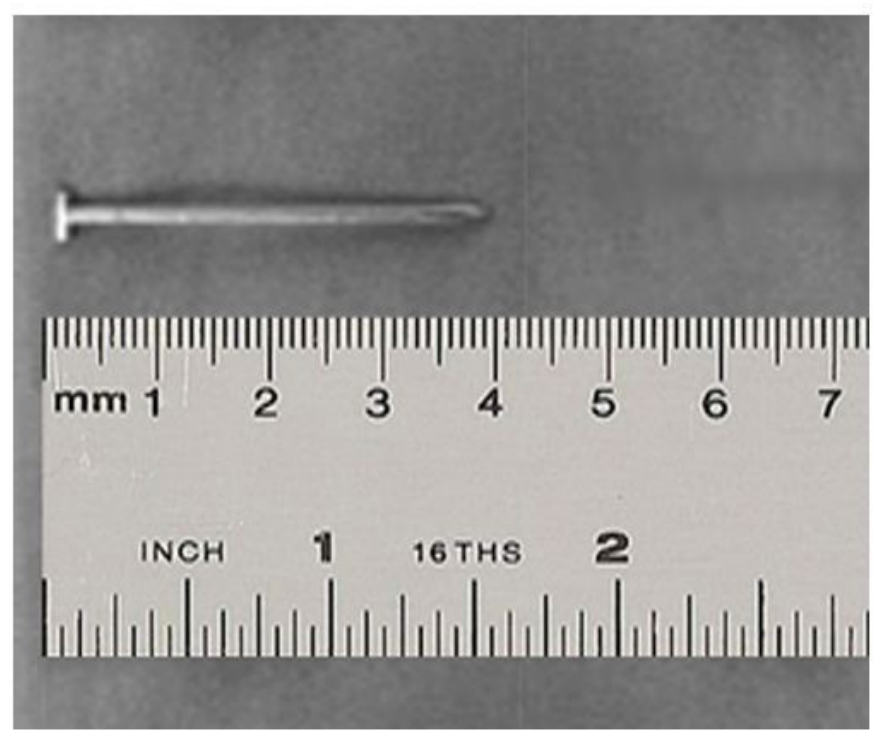

Figure 4: Postoperative image of the extracted nail of 4-cm in length

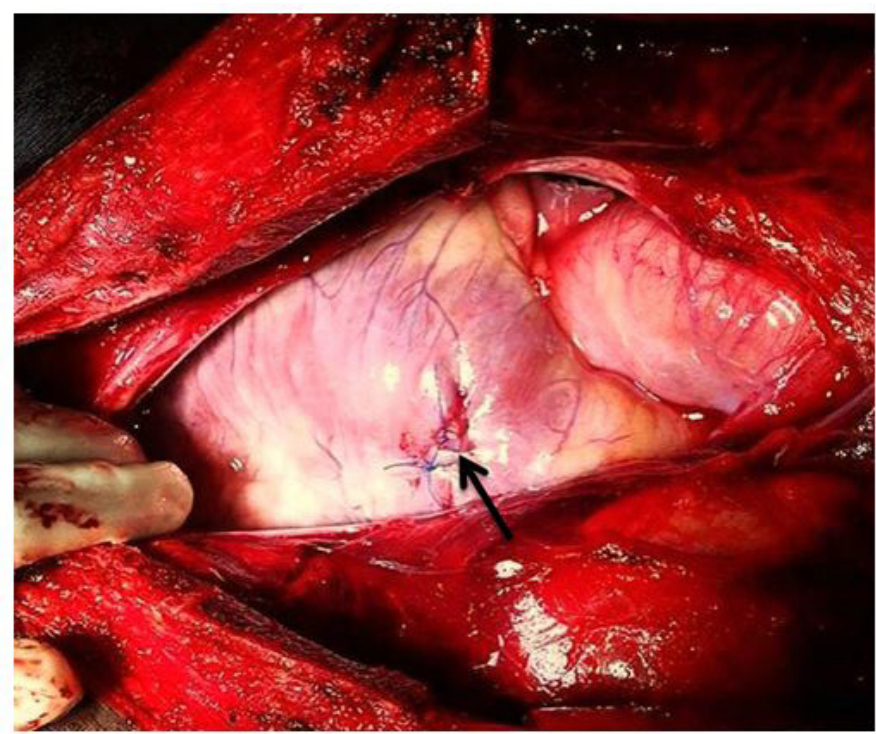

Figure 5: Intraoperative view of the direct repair of right ventricular injury (arrow) through left anterior thoracotomy 


\section{Discussion}

Cardiac nail gun injury is a rare work-related hazard associated with $25 \%$ risk of mortality in male adults [6]. Most of these injuries are a result of accidental discharge of nail gun, commonly involve the right ventricle due to its anterior location, and associated with variable degrees of pericardial tamponade [7].

The clinical presentation of survivors varies in regard to their hemodynamic stability [8]. Most of the reported cases presented few minutes after trauma. Rare cases of delayed presentation or stable hemodynamic status at admission after cardiac nail gun injury were previously reported (Table 1$)[5,8,17]$. There is no standard reason for delayed presentation, but it could be related to stable hemodyamic status and invisible non-bleeding pinpoint skin wound $[8,13]$. In our case, the delayed presentation of pericardial tamponade after accidental nail gun injury is related to absence of annoying symptoms after trauma. The nail wedged in the soft tissue, costal cartilage and pericardium without a complete penetration through the cardiac chambers. The tip of the nail hit the right ventricle during cardiac movement causing a small puncture followed by gradual bleeding and formation of intra-pericardial hematoma.

\begin{tabular}{|c|c|c|c|c|c|c|c|c|}
\hline Author & Year & Age (y) & Gender & $\begin{array}{c}\text { Cause of } \\
\text { injury }\end{array}$ & $\begin{array}{c}\text { Physical } \\
\text { examination }\end{array}$ & Site of injury & Surgical approach & $\begin{array}{l}\text { Surgical } \\
\text { technique }\end{array}$ \\
\hline $\begin{array}{l}\text { Georghiou, et } \\
\text { al.[9] }\end{array}$ & 2003 & $14 \mathrm{y}$ & $\mathrm{F}$ & Blast injury & $\begin{array}{l}\text { An entry wound } \\
\text { at the level of } \\
\text { the } 8 \text { th IC space }\end{array}$ & $\begin{array}{l}\text { Right ventricular } \\
\text { muscular. }\end{array}$ & $\begin{array}{c}\text { Median } \\
\text { sternotomy with } \\
\text { CPB }\end{array}$ & $\begin{array}{l}\text { Removal of the } \\
\text { nail and repair } \\
\text { of injury with a } \\
\text { pledgeted suture }\end{array}$ \\
\hline Nolke, et al. [10] & 2005 & $\begin{array}{c}\text { Case 1: } \\
16 \text { y } \\
\text { Case 2: } \\
36 \text { y }\end{array}$ & $\begin{array}{l}\text { Cases } 1 \\
\text { and 2: } \\
\text { M }\end{array}$ & $\begin{array}{l}\text { Case } 1 \text { and } \\
\text { 2: Accidental } \\
\text { shot }\end{array}$ & $\begin{array}{l}\text { Cases } 1 \text { and 2: } \\
\text { Puncture (entry } \\
\text { point ) wound } \\
\text { under the left } \\
\text { nipple }\end{array}$ & $\begin{array}{l}\text { Case 1: Left } \\
\text { ventricular apex } \\
\text { Case 2: Right } \\
\text { ventricle }\end{array}$ & $\begin{array}{l}\text { Cases } 1 \text { and 2: } \\
\text { Left anterior } \\
\text { thoracotomy }\end{array}$ & $\begin{array}{l}\text { Cases } 1 \text { and 2: } \\
\text { Repair of the } \\
\text { defect with } \\
\text { pledgeted sutures }\end{array}$ \\
\hline $\begin{array}{c}\text { Straus, et al. } \\
\quad[11]\end{array}$ & 2006 & $62 y$ & M & $\begin{array}{l}\text { Suicidal } \\
\text { shot by a } \\
\text { pneumatic } \\
\text { nail gun }\end{array}$ & $\begin{array}{c}\text { An entry at left } \\
\text { anterior chest. } \\
\text { Hemodynamic } \\
\text { stable }\end{array}$ & $\begin{array}{l}\text { Two nails: One } \\
\text { within the left } \\
\text { ventricle, and } \\
\text { another one in } \\
\text { anterior mitral } \\
\text { valve leaflet. }\end{array}$ & $\begin{array}{c}\text { Median } \\
\text { sternotomy with } \\
\text { CPB }\end{array}$ & $\begin{array}{c}\text { Extraction of nails. } \\
\text { Repair of mitral } \\
\text { valve leaflet was } \\
\text { not required }\end{array}$ \\
\hline $\begin{array}{c}\text { Guo and Myers } \\
{[12]}\end{array}$ & 2008 & $25 \mathrm{y}$ & M & $\begin{array}{l}\text { Accidental } \\
\text { shot }\end{array}$ & $\begin{array}{c}\text { A nail } \\
\text { protruding at } \\
\text { the sixth left IC } \\
\text { space }\end{array}$ & $\begin{array}{l}\text { Anterior wall of } \\
\text { the right ventricle }\end{array}$ & $\begin{array}{l}\text { Median } \\
\text { sternotomy }\end{array}$ & $\begin{array}{l}\text { Extraction of the } \\
\text { nail after tying a } \\
\text { purse-string suture } \\
\text { around it }\end{array}$ \\
\hline $\begin{array}{c}\text { Tuladhar, et al. } \\
\text { [13] }\end{array}$ & 2009 & $49 y$ & M & Suicidal shot & $\begin{array}{l}\text { Two pinpoint } \\
\text { blood clots } \\
\text { near the } \\
\text { xiphisternum }\end{array}$ & $\begin{array}{l}\text { One nail in the } \\
\text { rectus insertion. } \\
\text { Another one } \\
\text { enters right } \\
\text { ventricular free } \\
\text { margin and exits } \\
\text { through the } \\
\text { inferior surface of } \\
\text { the left ventricle }\end{array}$ & $\begin{array}{c}\text { Median } \\
\text { sternotomy with } \\
\text { CPB }\end{array}$ & $\begin{array}{l}\text { Removal of both } \\
\text { nails. Wounds } \\
\text { were repaired and } \\
\text { buttressed }\end{array}$ \\
\hline $\begin{array}{c}\text { Comoglio, et al. } \\
{[14]}\end{array}$ & 2010 & $75 y$ & M & $\begin{array}{l}\text { Accidental } \\
\text { shot } \\
\text { (unnoticed } \\
\text { initially) }\end{array}$ & $\begin{array}{c}\text { A small wound } \\
\text { on the left chest } \\
\text { wall }\end{array}$ & $\begin{array}{l}\text { Left ventricular } \\
\text { wall }\end{array}$ & $\begin{array}{l}\text { Median } \\
\text { sternotomy }\end{array}$ & $\begin{array}{l}\text { Gentle removal of } \\
\text { the nail. Wounds } \\
\text { were repaired }\end{array}$ \\
\hline Jodati, et al. [8] & 2011 & $24 \mathrm{y}$ & M & $\begin{array}{l}\text { Accidental } \\
\text { shot }\end{array}$ & $\begin{array}{l}\text { Non-bleeding } \\
\text { pinpoint skin } \\
\text { wound }\end{array}$ & $\begin{array}{c}\text { Anterior mitral } \\
\text { leaflet }\end{array}$ & $\begin{array}{c}\text { Median } \\
\text { sternotomy with } \\
\text { CPB }\end{array}$ & $\begin{array}{l}\text { Removal of the } \\
\text { nail. Repair of the } \\
\text { anterior mitral } \\
\text { leaflet }\end{array}$ \\
\hline $\begin{array}{c}\text { Madani, et al. } \\
\text { [15] }\end{array}$ & & $17 y$ & M & $\begin{array}{l}\text { Accidental } \\
\text { shot }\end{array}$ & $\begin{array}{l}\text { A punctiform } \\
\text { entrance wound } \\
\text { at the } 2 \mathrm{nd} \text { left } \\
\text { IC space }\end{array}$ & $\begin{array}{l}\text { The trunk of } \\
\text { the pulmonary } \\
\text { artery without } \\
\text { transfixing its } \\
\text { posterior wall }\end{array}$ & $\begin{array}{l}\text { Median } \\
\text { sternotomy }\end{array}$ & $\begin{array}{l}\text { Extraction of the } \\
\text { nail after tying a } \\
\text { purse-string suture } \\
\text { around it }\end{array}$ \\
\hline $\begin{array}{l}\text { Michalsen, et al. } \\
{[16]}\end{array}$ & 2015 & $\begin{array}{l}\text { Case 1: } \\
3 \text { y } \\
\text { Case 2: } \\
37 \text { y }\end{array}$ & $\begin{array}{l}\text { Cases 1 } \\
\text { and 2: } \\
\text { M }\end{array}$ & $\begin{array}{c}\text { Case 1: } \\
\text { Accidental } \\
\text { shot } \\
\text { Case 2: } \\
\text { Suicidal shot }\end{array}$ & $\begin{array}{l}\text { Cases } 1 \text { and 2: } \\
\text { Left parasternal } \\
\text { puncture } \\
\text { wounds }\end{array}$ & $\begin{array}{l}\text { Cases } 1 \text { and } \\
\text { 2: Right } \\
\text { ventricle and } \\
\text { interventricular } \\
\text { septum }\end{array}$ & $\begin{array}{l}\text { Case 1: Median } \\
\text { sternotomy with } \\
\text { CPB } \\
\text { Case 2: Median } \\
\text { sternotomy with } \\
\text { intravenous } \\
\text { adenosine to slow } \\
\text { the heart rate }\end{array}$ & $\begin{array}{l}\text { Case 1: Nail } \\
\text { extraction through } \\
\text { small right } \\
\text { ventriculotomy } \\
\text { Case 1: Nail } \\
\text { extraction and } \\
\text { repair of } 2 \text { holes in } \\
\text { right ventricle }\end{array}$ \\
\hline
\end{tabular}




\begin{tabular}{|c|c|c|c|c|c|c|c|c|}
\hline Author & Year & Age (y) & Gender & $\begin{array}{l}\text { Cause of } \\
\text { injury }\end{array}$ & $\begin{array}{c}\text { Physical } \\
\text { examination }\end{array}$ & Site of injury & Surgical approach & $\begin{array}{l}\text { Surgical } \\
\text { technique }\end{array}$ \\
\hline Kulaylat, et al. & 2016 & $29 \mathrm{y}$ & $\mathrm{F}$ & Suicidal shot & $\begin{array}{l}\text { Bloodless } \\
\text { puncture } \\
\text { wound at right } \\
\text { 4th IC space }\end{array}$ & Right ventricle & $\begin{array}{c}\text { Median } \\
\text { sternotomy }\end{array}$ & $\begin{array}{l}\text { Nail extraction } \\
\text { and primary } \\
\text { repair of torn } \\
\text { myocardium }\end{array}$ \\
\hline Ho, et al. [17] & 2017 & $51 \mathrm{y}$ & M & Suicidal shot & $\begin{array}{l}\text { One puncture } \\
\text { wound at the } \\
\text { right sternal } \\
\text { border in the } \\
4 \text { th IC space }\end{array}$ & $\begin{array}{c}\text { Anterior right } \\
\text { ventricular wall } \\
\text { and diaphragm }\end{array}$ & $\begin{array}{c}\text { Median } \\
\text { sternotomy with } \\
\text { CPB }\end{array}$ & $\begin{array}{c}\text { Removal of the } \\
\text { nail and closure } \\
\text { of the two heart } \\
\text { wounds and } \\
\text { diaphragm. }\end{array}$ \\
\hline
\end{tabular}

Delayed pericardial tamponade after penetrating cardiac injury is a challenging diagnostic and therapeutic entity, with several proposed mechanisms including clot sealing a partial tear associated with slow leak into pericardium or sudden dislodgment followed by rapid accumulation of blood [18]. In stable patients and in those with unclear presentation, imaging modalities particularly echocardiography have a vital role to confirm the presence of pericardial tamponade [13]. Chest computed tomography (CT) scans can be used to confirm the intra-thoracic position of the nail, and to detect pericardial effusion [8]. The stable status of our case at admission gave us the chance to perform preoperative CT and bedside echocardiography [14-17].

A controversy remains regarding the conservative management and pericardiocentesis in patients with no tamponade and stable hemodynamic status. Percardiocentesis can serve as a temporary life-saving measure, particularly as a bridge to definitive therapy $[18,19]$. The presence of pericardial tamponade indicates an emergent surgical intervention via median sternotomy or thoracotomy according to the location of cardiac injury [20]. Emergency department thoracotomy is favored for the hemodynamically unstable or pulseless patient [19]. In our case with unusual presentation, we preferred anterior thoracotomy in the operating room as the hemodynamic status was query stable and the imaging studies excluded penetration of the nail into cardiac chambers or major blood vessels.

\section{Conclusion}

Adequate training and applying of the security systems are essential to prevent accidental nail gun injuries. In addition to firearm and stab wounds, nail gun is an essential cause of penetrating cardiac injury. Cardiac nail gun injury is a rare emergency condition requires early diagnosis and immediate intervention to reduce the rate of mortality. High index of clinical suspicion and use of the best and fastest imaging modalities are useful for successful management of stable patients. Unstable hemodynamic status after penetrating trauma to the cardiac box raises the alert for pericardial tamponade. Aggressive approach with proper resuscitation and avoid of time consuming investigations are crucial for unstable patients with penetrating cardiac injury.

\section{References}

1. Campbell NC, Thomson SR, Muckart DJJ, Meumann CM, Van Middelkoop I, et al. (1997) Review of 1198 cases of penetrating cardiac trauma. Br J Surg 84: 1737-40.

2. Singaravelu KP, Saya RP, Pandit VR (2016) Early diagnosis of penetrating cardiac and pleural injury by extended focused assessment with sonography for trauma. Heart Views 17: 151-3.

3. Beaver AC, Cheatem ML (1999) Life-threatening nail gun injuries. Am Surg 65: 1113-6.

4. Zhang W, Cao L, Hu S, Huang X, Yang Y (2014) Nail gun penetrating cardiac injury in a young child. Lancet 384: 828.

5. Kulaylat AN, Chesnut CH, Patel S, Rocourt DV, Clark JB (2016) Penetrating cardiac nail gun injury in a child. Pediatr Emer Care 32: 536-7.

6. Miranda WGC, Fuentes EJ, Hernandez NE, Salazar LRM, Parizel PM (2017) Penetrating cardiac injury and traumatic pericardial effusion caused by a nail gun. J Korean Soc Traumatol 30: 21-3.

7. Temple AD, Fesmire FM, Seaberg DC, Severance HW (2013) Cardiac injury due to accidental discharge of nail gun. J Emerg Med 44: 161-3.

8. Jodati A, Safaei N, Toufan M, Kazemi B (2011) A unique nail gun injury to the heart with a delayed presentation. Interact Cardiovasc Thorac Surg 13: 363-5.

9. Georghiou GP, Birk E, Nili M, Stein M, Vidne BA, et al. (2003) Images in cardiovascular medicine. Direct nail injury to the heart without functional or hemodynamic compromise. Circulation 107: e92-3.

10. Nolke L, Naughton P, Shaw C, Hurley J, Wood AE (2005) Accidental nail gun injuries to the heart: diagnostic, treatment, and epidemiological considerations. J Trauma 58: 172-4.

11. Straus JP, Woods RJ, McCarthy MC, Anstadt MP, Kwon N (2006) Cardiac pneumatic nail gun injury. J Thorac Cardiovasc Surg 132: 702-3.

12. Guo LR, Myers ML (2008) Penetrating cardiac injury: the nail gun, a potentially dangerous tool. Can J Surg 51: E7-8.

13. Tuladhar S, Eltayeb A, Lakshmanan S, Yiu P (2009) Delayed presentation of right and left ventricle perforation due to suicidal nail gun injury. Ann Card Anaesth 12: 136-9.

14. Comoglio C, Sansone F, Boffini M, Ribezzo M, Rinaldi M (2010) Nail gun penetrating injury of the heart mimicking an acute coronary syndrome. Int J Emerg Med 3: 135-7.

15.Madani M, Drissi M, Ajaja MR, Rifai M, Moutaouakkil, et al. (2012) Nail gun may cause heart injury: A young adult’s misadventure. Int Emerg Nurs 20: 98-101. 16. Michalsen KL, Iguidbashian JP, Kyser JP, Long III WB (2015) Low-velocity nail-gun injuries to the interventricular septum: Report of two cases, One in a Child. Heart Inst J 42: 393-6.

17. Ho S, Liu B, Feranec N (2017) Self-inflicted cardiac injury with nail gun without hemodynamic compromise: A case report. Cureus 9: e971. 
18. Almehmadi F, Chandy M, Connelly KA, Edwards J (2016) Delayed tamponade after traumatic wound with left ventricular compression. Case Rep Cardiol 2154748 .

19. Chirumamilla V, Prabhakaran K, Patrizio P, Savino JA, Marini CP, et al. (2016) Pericardiocentesis followed by thoracotomy and repair of penetrating cardiac injury caused by nail gun injury to the heart. Int J Surg Case Rep 23: 98-100.

20. Eren E, Keles C, Sareyyupoglu B, Bozbuga N, Balkanay M, et al. (2004) Penetrating injury of the heart by a nail gun. J Thorac Cardiovasc Surg 127: 598. 